\title{
Employment Policy and the Labor Mobility in the Western Balkans
}

\author{
Hasan Jashari \\ Zemri Elezi
}

Professor, South East European University, Macedonia, Rr.llindenit, p.n, Tetove, 1200

h.jashari@seeu.edu.mk,z.elezi@seeu.edu.mk

\section{Doi:10.5901/ajis.2014.v3n6p333}

\begin{abstract}
Industrial capitalism created major changes in society and in the demand for workforce through industrialization and urbanization. This greatly influenced on the movement of large number of workers in global proportions. But, it's a question whether entering the European Union of state candidates will make the same move? With the entry of central European countries into the EU, Bulgarians, Romanians wandered into westward in a big number. Will the entry of Croatia, Montenegro, and Serbia into the EU cause the same situation? How will their social mobility be? Croatia has at least 20,000 qualified tourism workers for the next summer season in the Adriatic Sea: Cooks, waiters, builders who can choose works as well as working conditions in the new EU member. The coast of Montenegro, a collection of world businessmen and rich people, calls for some 3,000 workers from Macedonia only. All Western Balkan countries, after the shock of transition, slowly are recovering and intentions and measures to reduce the number of workers in employment offices are rising. Macedonia claims that unemployment has decreased to $29 \%$ in the contrast to $21 \%$ in Serbia and Bosnia, and Kosovo Albania still have high figures. But, will public employment policies and a range of measures, among which the most common are employment under temporary contracts, reducing unemployment among young people, women, social cases, of handicapped people yield results? According to these logics of employment policy and the labor movement and the labor market, i.e. changes in the labor market, the logic is imposed when will Western Balkan countries join the EU and replaces the labor force with workers from Afghanistan, Bangladesh of Eritrea? Through these statistical indicators and various data - Interpretation of them will elaborate this phenomenon which is quite important for the reality in post-communist Western Balkan
\end{abstract}

Keywords: Politics, Public, Labor Force, Western Balkans, European Union, Mobility

\section{Introduction}

\subsection{Research Methodology}

The material for the study was gathered through qualitative interviews with this survey will collect data on employment policies and mobility of seasonal workers as extremely important problem for all societies with emphasis on western Balkan countries. For this reason it will be collected factual material of first and hand second. The collected material will be selected and interpreted in the form of tables and average sizes. We will also use direct observation and conversation with people who are part of trainings for employment policies.

\subsection{Work and industrial capitalism}

Industrial capitalism, by industrialization and urbanization created major changes in society and in the demand for workforce. This influenced greatly to the movement of workers in large national and international terms. Opening new business induced migration of the population and their living nearby their job. In this way of industrialization, urbanization took off, for example, only six cities with more than 10,000 habitants could be found in United States in 1800; this number increased tenfold in the half century that followed.

With the increasing of the number of workers there was a development of the organizations for their rights as well as the care and control of the society for the work and the industry. In the last decade, with the entry of central European countries into the EU, Poles, Bulgarians, Romanians, they all went to western countries in a big number. The question is: "Will the same thing happen with the entry of Croatia, Montenegro and Serbia as well?

Historically, the British industrial revolution after 1800 probably prompted a series of social changes and as a result 
the industrialization and urbanization of the society as well. Employment in England took off after the discovery of the steam machine and putting it in function of the textile industry and other industrial works. The demand for technical manpower and technological revolution spurred employers to require educated, resourceful workers that can work with complex manufacturing operations. Drucker relates the term Capitalism to a system that together with a range of technological innovations had the had the capacity of conquering the globe and creating a new world civilization, that converted capitalism into "Capitalism" and technical and technical advances into the "Industrial Revolution" ( Drucker, P. F. 1994,1993, page 5-15.)

It is known that the dramatic development of railway and automobile industries especially after putting the ribbon moving in 1913 from FORD manufacturer induced transport of goods, people and material goods. This type of transportation facilitated and opened new horizons for the development and overall social planning in the future. Subsequent developments were also hopeful steps toward social welfare. Employers and workers had also benefits. The Highland Park plant in Michigan begins operations as the first moving automobile assembly line in the world. Jan. 5, 1914: Ford begins offering $\$ 5$ per day for eight-hour work days and 15,000 job seekers clamor for 3,000 jobs at the Model T Plant in Highland Park. The previous pay rate was \$2.34 per day for nine hours). The opening of businesses and workshops urged a dramatic trade growth... All these played a part of transformations of dozens of willages and small towns into humming industrial cities.

Around the 1920s, voluntary immigration from Europe has provided millions of new workers to the economy. In these waves were included more and more workers and civilians from the Balkans. This is the time after the historical event of ship Titanic and the flow and enthusiasm of people to seek a ticket more but also more rich people who go abroad as investors.

The central question is that how labor mobility in the postmodern time will change the global economy? Peter Drucker (1993) and Manfred B.Steger (2003) say that this also will be a dramatic change as to involve with working in a distance. On the other hand distance work, concentrating on digital infrastructure, created an interdependence relation between communities and places. So, to be globally competitive in the job market, one must speak the language appropriately, to have an appropriate software is more effective than being from the same region of the metropolis with the seekers of the services (Mitchel.J, W., page 4 )

\section{Theoretical Aspects}

A principle question becomes the issue of why employment policies are important to study? The answer is because of the high number of Balkan citizens who are registered as job seekers at the Employment Office. Directly related to the employment policies is unemployment as a very meaningful and complex social phenomena. Even though a very significant number of researchers deals with labor and unemployment issues; it is still not so helpful for alleviating unemployment, especially in the Balkans in the post communist era. Unemployment strikes young men, women with low education, those without qualifications and low skills, people with disabilities, the sick, immigrants and minorities.

But, watching from socio-economic, work and employment represent an important precondition for the social life.aspect. In 2005, about 65 per cent of the EU- 25's population aged between 15 and 64 were employed. In 9 member states, over 67 per cent were employed. Naturally, with the growing number of workers there are also created unions or union movements. These institutions increase demands and pressures to economic elites, but also to governments, for the rights of workers. So here we are dealing with governmental policies on employment and workers movements. Unemployment is closely related to the employment policies. Every industrialized society deals with unemployment, in some of them more expressed and in some less; some are young, some leave the job for a better job, some do not have the requisite qualifications and some are sick.... So the causes of unemployment are varied and numerous. But governments and economies separately establish themselves called unemployment called structured unemployed. Jobs disappear and occupations become obsolete, as business close in the face of foreign competition and as a recession force layoffs and bankruptcies.... (Macionis J.J., \& Plummer, K., 2008,page 486,) . The next question is what is the role of state institutions in hiring people? Thus, " government policies try to facilitate job search in different ways" (Mankin, N. G, et.al, 2012:172). For example, "One way is through employment agencies administered by the state or by working centers which disseminate information about job vacancies" (Ibid). Exactly this way will be taken for analysis in this paper.

Refers to Ritzen and Zimmermann ( 2014:4-5) "Wage inequality increased in Europe in the period 2000-2010 mostly as a result of the long-run changes in the production structure in which non-routine work became increasingly more important, whereas the relevance of routine work decreased." 
Because prices are sticky, various types of government policy have short-term effects that differ from their longterm effects. When the government reduces the quantity of money, for instance, it reduces the amount that people spend. Lower spending, together with prices that are stuck too high, reduces the quantity of goods and services that firms sell. Lower sales, in turn, cause firms to lay off workers. Thus, the reduction in the quantity of money raises unemployment temporarily until prices have fully adjusted to the change. (Joshua G., at all, 21012, pp 3-5)

If we refer to Karl Marcs (1984) who criticizes industrial capitalism and names it as a wild form of exploitation of the working class as naked from the production means ownership and the capitalist class as an owner and exploitation. He considers the work fruitfulness, its growth as a danger for the growth of exploitation and social inequalities. The major modern classes are "the owners merely of labor-power, owners of capital, and landowners, whose respective sources of income are wages, profit and ground-rent."

\section{Employment and Mobility in Europe}

Debates and tales for the crowd of workers from Bulgaria and Romania, for asylum seekers of different races, religions and countries in western Europe have remained as episodes of excessive concerns.

The data of the European Commission (2004) may conclude that mobility of workers within the Union is small. Between 1991-2000, for 10 years only 15\% of the citizens of this organization have changed residence because of work in another country. If statistics were referred, this phenomenon is mostly present as due to labor migration. Therefore, according to data that migrants trigger work as a reason for their migration, lead: Italians with $61 \%$, Portuguese $46 \%$ and $30 \%$ Spanish. We can reach the conclusion that freedom of movement of labor within the EU member states is not used enough and that there are still administrative, legal and practical obstacles for its function? But it is known that this negative mobility has negative impact on economic development, employment and professional education of workers. On the other hand sociologists draw attention that this speaks about the weakening of social cohesion within the EU. Recent years with the introduction of the global economic crisis and increasing austerity policies, most European countries narrowed their generosity on mobility because of the fact that austerity policies began to increase unemployment. In 2002 the European Commission brought an Action plan for mobility and professional training. Some countries like Austria, Germany, Sweden, Denmark, Portugal brought various measures to improve geographical mobility of workers, sectoral employment, mobility of unemployed workers, within public administration (case of Denmark), (Kapural, M.,2005, 87-92)

Scientific research talk about it that Europe is still a place where employees stay at home compared with America. In 2011, 2.7\% of Americans have lived a year ago in another of the 50 states. In contrast, only $0.2 \%$ of Europeans had migrated from a year ago.

But people move around or stay stuck for many reasons. Economic question that matters most of all is how the workers are willing to take the road to look for work when times get tough in the places where they live. The more workers are prepared to move when needs arise, and go there where employment is available, the more easily economies will be able to cope with the unemployment and employers will be able to find workers with the skills they need.

The data used in the survey in 2011 for example, show that the number of registered immigrants in Germany from Italy and Spain rose by about $40 \%$ between the first half of 2012 and the first half of 2013 . The number of registered immigrants from Portugal grew by more than $25 \%$ over the same period. (http://www.economist.com January 13th 2014,) /2014/01/european-labour-mobility,07.03. 10:50 hrs )

The Forum of the Organization for Security and Cooperation of Europe (OSCE) through a study and a manual tries to help states, separately those of Mediterranean who are the first in hitting migrant job seekers, to strengthen their efforts to build employment policies and practical approach to a genuine and flexible management of labor migration from the country of origin in place of destination (2007, page 1-6).

\section{Employment Strategy in Relation to the European Framework 2010-2020}

The global financial crisis has shown however the weaknesses of the EU economy, too. Its effects have virtually erased all the gains of the last decade in terms of economic growth and creation of job positions. Europe 2020 must be based on issues, such as: a) smart growth, which means economy relied on knowledge and innovation; b) sustainable growth that promotes a more efficient use of natural resources and energy; $c$ ) inclusive growth, which should enable the territorial and social cohesion. (The new strategy 'Europe 2020') defines where the EU should be after 10 years through quantitative targets, such as:

- Reducing the number of people living below the poverty line by $25 \%$, this actually means the redemption of 
more than 20 million people from poverty. This analysis examines the incoherencies characterizing the current generation of labor migration policies of the EU and security challenges of a global approach based on migration rights.( Carrera, S., et all,2011, page 1-5)

\section{Social and Economic Aspects of Mobility}

Labor mobility consists of changes in the location of workers across physical space (geographical mobility) and across a variety of jobs (job mobility). At the aggregate level, labor mobility conveys significant economic benefits. Workers reallocation through regions allows the use of additional resources. Meanwhile, reallocation across sectors makes it possible to use the new technologies and the growth of new industries. At the individual level, mobility allows for improvements in economic circumstances or aspirations of those skills which are poor matches for the job or the country in which they are located. Occupational mobility can be horizontal (within a broad class of jobs related to socio-economic status) or vertical (from worse to a better job). But the next question is whether the industrial capitalism is a magnet for the industrialization and mobility of workers within the world? If we refer to Giddens (2005:573) we will encounter the case of Chicago and New York in which cases from 1850 until 1900 of domestic sources increased to 20 times in the number of population. So, the opening of new businesses requires manpower, workers are placed near their working place and therefore the great demand for manpower creates growth of large urban centers. This has greatly influenced the movement and mobility of the large number of workers in global terms. But now the question is whether with the entering of candidate states in the European Union will make the same move? Will migrants from Afghanistan, Bangladesh, Syria, and Somalia ... that would replace Balkan workers are going to go to the West? Of course they will.

Although many of these movements were only temporary, the most stable movement from the countryside to cities was essential to the growth of industry and labor productivity, urbanization and population education.

\section{Employment Policies and Mobility in the Western Balkans}

The Western Balkan countries are characterized by high unemployment and by various government attempts by different measures to reduce unemployment. But these measures often correspond to the firefighters actions. On the one hand, a problem is repaired and governments remain pending for another appearance. The role of trade unions or workers' Unions is declining. It often happens for the elite unions to be in good relationships with governments and employers. Another problem is the fact that by wanting to acquire certain statuses for membership in EU, governments implement measures, projects, undertake inadequate and unstudied reforms for the nature of the problems and so damage workers. Prolonged transition of several countries also presents a serious problem to the qualitative step from older forms of public policies in economy and employment policies. Low wages and the departing of highly educated youth towards west is also a part of this social mosaic. Almost all countries in the world $60-80 \%$ of the unemployed have no work experience.

Scientific researches show that workers who move to other countries for a better income, in most cases make horizontal motion. This means that their social role changes. Some of them make a move up and down, doing much more difficult jobs than the one they did in their homeland. But their social position improves by taking higher salaries. But our study object is the topic of how the mobility and labor market situation in Western Balkans in 2014 is?

Today, Croatia lacks for each year at least 20,000 qualified tourism workers; cookers, waiters, builders, utilities workers ... The coast of Montenegro, a gathering place of global businessmen and wealthy people, calling for workers of all colors and that only 3000 to 2014 only from Macedonia.

All Western Balkan countries, after the shock of transition, slowly recover and intentions and measures to reduce the number of workers in employment offices are in growth. Even though Macedonia claims that unemployment has decreased to $29 \%$, with $21 \%$ Serbia but Kosovo Albania still have high numbers.

Chronic unemployment in the Western Balkan countries threatens the stability of the current goal of European Union membership. Balkan states try to reduce unemployment through various measures. But will public employment policies and a range of measures, among which the most common are employment under temporary contracts, reduce unemployment among young people, women, social cases, handicap would yield results? Experts of the United Nations Programme believe that the Western Balkan region in 2020 will be a regional destination and immigration for workers in some parts of Europe and Asia.

Employment Agency of Montenegro has prevented new employment permits to foreigners, because until May quota has already exceeded more than 1500 work permits, and instead the planned number of 6.208 there are issued to 7.758 work permits, writes "Pobjeda" (Pobjeda 05/12/2014 ). On the other side, Montenegro is preparing a new law on 
employment, which will be containing tougher rules for employment of foreigners. More than $80 \%$ of issued work permits are given to perform works by unskilled workers in: tourism, construction, agriculture and trade. Statistics show that foreign workers come mainly from Serbia 43.93\%, Bosnia and Herzegovina 21, 08\%, and 13.71 coming from Russia, Macedonia 6.66\%. Etc. Demand for workers with completed higher education is only 5.5 percent. (Tanjug) http://www.seebiz.net/moja -karijera/trziste-rada, 24.05, 14, 12.30). If we make a comparison with Western European countries we can say that the west will constantly need workforce of high qualifications. (more: http://www.dailymail.co.uk/ news/article-2638497 May 25, 2014 ).

Government of Macedonia in the summer of 2014 energized measures to increase employment. Hence, in early July announced public calls for the unemployed who are beneficiaries of social assistance and subsidized employment of MKD 17,000 in 6 month period obligation for the employer to keep for 6 months more. The program consists of a three months training by the employer and this move has more to do with the preparation of employee with the working conditions and future tasks. For this purpose from the budget are allocated 22.58 million denars. From 2007 to $2013 \mathrm{In}$ this training program participated 7,278 people and 6,591 of them are employed. (http://www.mkd.mk/makedonija/ ekonomija/novi-MERKI-za-zgolemuvanje-us-vrabotenosta, 07.2014, $10.25 \mathrm{hrs}$ ). In Macedonia as well as in other Balkan countries the employment of young people and their escape to the west presents a problem to be issued.

On the other hand with regard to Serbia, European Union helps in employment policies with 2 million Euros. It is a project which aims to improve the effectiveness of employment policies in Serbia as a candidate country which need to adapt national policies in the law, employment and professional shaping with European standards. (www.rts.rs , 2014).

Improvement of the chances for employment of the citizens, especially for women and young people is the main challenge of economic social development for Kosovo for the year 2014. The idea stands for creating more jobs and thus lower unemployment. (Jean-P. O. 28.02.2014). The focus should be on policies that increase domestic productivity and effective measures to ensure the high quality work places for the population especially for young people of this country.

On the other hand, Albania and Albanians are the country with the most mobile work force, legal and illegal. It is well known that the number of Albanian workers in Greece is over 500,000 and over 200,000 in Italy. The government has drawn "National strategy for employment and higher skills and better work for all men and women" national strategy for Employments and skills 2014-2020 ${ }^{1}$

\section{The Case of a Worker and his Mobility}

The employee N. N. from Tetova has worked for more than two decades in the textile combine Teteks. He has finished high school. After the continuous declining of wages his working place changed and his income was only 5,000 MKD that are equal to 82 Euros. He decided to leave the job and work in agriculture - laborers who had exercised as a child as an additional work. In the beginning of 2013 a friend of his suggested that you can find a seasonal job in Osijek, Croatia also in agriculture. The first contacts were made and before March 1 ${ }^{\text {st }}, 2013$ he was at the Croatian employer and made a range of agricultural work including supply and sale, along with the owner of the products. He was getting food from the owner, they often ate together. He was living in the farm. His salary was 6,000 Croatian Kuna that were equal to approximately 800 Euros; so twice the salary of a high school professor in Macedonia.

In order to find this job, his friend should collect lots of permissions for work and for staying in the country as well.

The employee is satisfied with his incomes even though he worked overtime and the employer didn't recompense for that.

This document was prepared with the technical support of ILO-EU project IPA 2010 for Human Resources Development project in Albania and ETF Frame. ${ }^{1}$. 
Table 1: Full time and part time employed by educational attainment and gender, 2012

\begin{tabular}{|c|c|c|c|c|c|c|c|c|c|}
\hline \multicolumn{3}{|c|}{ Employed persons } & \multicolumn{3}{|l|}{ Full time } & \multicolumn{3}{|c|}{ Part time } & \multirow{2}{*}{ Educational attainment } \\
\hline Total & Men & Women & Total & Men & Women & Total & Men & Women & \\
\hline 650554 & 393092 & 257462 & 608716 & 369914 & 238802 & 41838 & 23177 & 18661 & Total \\
\hline 3044 & 1698 & 1347 & 2349 & 1377 & 972 & 696 & 321 & 375 & Without education \\
\hline 21088 & 10088 & 11001 & 16351 & 7896 & 8455 & 4737 & 2191 & 2546 & $\begin{array}{l}\text { Incomplete primary and } \\
\text { lower secondary education }\end{array}$ \\
\hline 120579 & 79533 & 41046 & 107817 & 72822 & 34996 & 12762 & 6711 & 6050 & $\begin{array}{l}\text { Primary and lower } \\
\text { secondary education }\end{array}$ \\
\hline 348957 & 220683 & 128274 & 331105 & 209567 & 121538 & 17852 & 11116 & 6736 & $\begin{array}{l}3 \text { and } 4 \text { years of secondary } \\
\text { education }\end{array}$ \\
\hline 19903 & 10657 & 9246 & 19265 & 10394 & 8870 & 638 & 263 & 375 & Higher education \\
\hline 136982 & 70432 & 66549 & 131829 & 67858 & 63971 & 5153 & 2574 & 2579 & $\begin{array}{ll}\begin{array}{l}\text { University } \\
\text { education }{ }^{1)}\end{array} & \text { level } \\
\end{array}$ \\
\hline
\end{tabular}

Statistical Review (2013)

1) University level education includes: university level education, Master's degree and Doctorate (Ph.D) From the table 1 we can see that the total number of employees in the RM of 2 million inhabitants is 650,554 , of whom 393,092 are men and 2,574,662 are women. Here we note that the number of males constitute $60.1 \%$ of the employees. men with secondary education are employed as 220683 from 348957 all employed professional women in this category are 128,274 . Thus, only $36,7 \%$ of the employees are with high school education

So, employment policies in Macedonia in the future should be oriented towards gender equality in employment and hiring with additional measures for employment of women with secondary education.

\section{Conclusions}

Industrial capitalism, created through industrialization and urbanization major changes in society and in the demand for workforce. The opening of new businesses induced migration of the population and their situation close to their job.

- Labor and employment represent an important precondition for social life. In 2005, about 65 per cent of the EU-25's Population Aged between 15 and 64 were employed. In nine member states, over 67 per cent were employed.

- The data from the European Commission (2004) conclude that the mobility of workers within the Union is small. During 1991-2000, for 10 years, only $15 \%$ of the citizens of this organization have changed residence due to working in another country.

- Freedom of movement of labor within the EU member states is not used enough and that because there are still administrative, legal and practical obstacles for its functional aspects. But is known that this has hampered mobility has negative impacts on economic growth, employment and vocational education.

- In the western Balkans there is a movement by workers toward west, which they do so legally and illegally, especially during summer in the for Croatia and Montenegro coastline.

- The Government of Macedonia in the summer of 2014 will reactivate measures for increasing employment.

- In the future employment policies in the Western Balkans should be an object of regional cooperation and using of best practices of the EU to reduce unemployment and free labor mobility of workers within Europe.

\section{References}

Ritzen J. and Zimmermann.K, (2014). A vibrant European labor market with full employment, IZA Journal of European Labor Studies 2014, 3:10 doi:10.1186/2193-9012-3-1

Marx,K. Kapital,1984 tom III, Klasna teorija, Beograd, page 180-185: Kultura,

Boeri T., Brucker H. The impact of Eastern Enlargement on Employment and labor market in the EU member states. Final Report: Berlin: Milan.. page 87-88 : European Integration Consortium

Handbookon- Establishing Effective Labour Migration Policies Mediterranean edition (2007).

Labour Office (ILO); Design and Typesetting: Vienna : 2007 Organization for Security and Co-operation in Europe (OSCE), International Organization for Migration (IOM); ;

StATISTICAL REVIEW: Population and Social Statistics, (2013) "Dame Gruev"- 4, Skopje: Publisher State statistical Office of 


\section{Macedonia.}

Mitchel.J,Viliam,( 2004) E -topia, Urban Life , Jim-But not as we know it,Publisher in Macedonian, Magor, Skopje: COBISS,.ME.ID

Carrera,S,Atger,F.A. Guild E., and Kostakopoulou,D.( 5 April 2011). Labour Immigration Policy in the EU: A Renewed Agenda for Europe 2020 No. 240, page 1-5)

Joshua Gans, Stephen King, Robin Stonecash, N. Gregory Mankiw, (2012). Principles of Economics, 5th Ed., (Australia) CengageBrain: Cengage Learning Australia Pty Limited

Macionis J.John \&Plummer,J. Ken, (2008) Sociology, 4th Edition,Macionis: Prentice Hall.Page 486,

Mitchel.J,Viliam,( 2004) E -topia, Urban Life , Jim-But not as we know it, Publisher in Macedonian, Magor,Skopje COBISS.

Drucker, P. F. (1994).(1993). Industrial Revolution (1993: The Post-Capitalist society. Neww Yoyrk,: HaarperBussines. Page 5-15

Giddens A., (2005,)Sociology Cities and Urban Space, $4^{\text {th }}$ Edition, Blackwell Publisher page 573

Steger B. M. ( 2003). Globalizimi: Hyrje e shkurter, perkth. Hamlet Bezhani, Tirane, Co-PLAN

Kapural, M. (2005) . Poglavlje 4. Sloboda kretanja radnika u Prosirenoj Evropskoj Uniji I njezin utjecaj na Hrvatsku. Zagreb : Agencija za zaštitu trišnog natjecanja

Natioanl strategy for employment and Higher skills and better work for all men and women" national strategy for Employments and skills (2014-2020). This document was prepared with the technical support for Human Resources Development project in Albania and ETF Frame: of ILO-EU project IPA 2010.

\section{Reference to a Web Source}

European labor mobility on the move. European labor mobility On the move http://ec.europa.eu/immigration/tab3.do?sub Sec=41\& language $=7 \$$ en, $03.07 .2014 .11,15 \mathrm{hrs}$

http://www.economist.com/blogs/freeexchange/2014/01/european-labour-mobility,London, 03.07.2014, 10:50 hrs

(Tanjug) http://www.seebiz.net/moja -karijera/trziste-rada/crna-gora-stop-stranim-radnicima /, 24.05, 14, $12.30 \mathrm{hrs).}$

Evropska unija . http://www.rts.rs/page/stories/sr, 15.07.2104, 12, 25 hrs 
